\title{
Hubungan pengetahuan dengan perilaku pencegahan infeksi masa nifas di RSUD Wonosari
}

\section{Relationship between knowledge and postpartum infection prevention behavior in RSUD Wonosari}

\author{
Marsela Renasari Presty ${ }^{1 *}$, Djaswadi Dasuki ${ }^{2}$, Yuli Isnaeni ${ }^{3}$ \\ ${ }^{1}$ Akademi Kebidanan Panca Bhakti, Jl. A.Yani II, Kubu Raya 78391, Indonesia \\ ${ }^{2}$ Universitas Gajah Mada, Jl. Farmako Sekip Utara, Yogyakarta 55281, Indonesia \\ ${ }^{3}$ Universitas 'Aisyiyah Yogyakarta, Jl.Siliwangi (Ringroad Barat) No.63, Mlangi, Nogotirto Gamping, \\ Sleman 55292, Indonesia \\ 1'marselarena1605@gmail.com*; 3isnaeniyuli@unisayogya.ac.id \\ *corresponding author \\ Tanggal Submisi: 20 November 2020, Tanggal Penerimaan: 14 Desember 2020
}

\begin{abstract}
Abstrak
Salah satu faktor penyebab tertinggi kematian ibu nifas adalah kurangnya informasi yang mempengaruhi perilaku dari ibu nifas dalam perawatan nifas. Tujuan dari penelitian ini adalah mengetahui hubungan pengetahuan dengan perilaku pencegahan infeksi masa nifas di RSUD Wonosari. Penelitian ini merupakan penelitian kuantitatif dengan rancangan penelitian cross sectional. Dari uji statistik yang dilakukan, diketahui bahwa responden dengan kategori pengetahuan yang tinggi dan berperilaku kurang baik terhadap pencegahan infeksi ada 31 responden, sedangkan responden dengan kategori pendidikan rendah dan memiliki perilaku yang baik ada 25 responden. Adapun nilai $\mathrm{p}$ value yang diperoleh adalah 0,286. Hasil ini menunjukan bahwa tidak ada hubungan antara pengetahuan dengan perilaku pencegahan infeksi.
\end{abstract}

Kata kunci: pengetahuan; perilaku; pencegahan infeksi; nifas

\begin{abstract}
One of the highest causes of maternal mortality is the lack of information that affects the behavior of postpartum women in postpartum care. The aim of this study was to determine the relationship between knowledge and postpartum infection prevention behavior in RSUD Wonosari. This research is a quantitative study with a cross sectional study design. The statistical test performed obtained that there were 31 respondents with high knowledge category and poor behavior towards infection prevention, while 25 respondents with low education category and good behavior. The $p$ value obtained was 0.286 . These results indicate that there is no correlation between knowledge with infection prevention behavior.
\end{abstract}

Keywords: behavior; infection prevention; knowledge; postpartum

\section{PENDAHULUAN}

AKI di Indonesia pernah mengalami kenaikan dengan jumlah 359 kematian ibu per 100.000 kelahiran hidup di tahun 2012. Pada tahun 2015 AKI kembali 
mengalami penurunan dengan jumlah 305 kematian ibu per 100.000 kelahiran hidup. Sedangkan AKB terus mengalami penurunan dengan jumlah 22,23 per 1.000 kelahiran hidup. Kematian ibu di Indonesia disebabkan oleh banyak hal. Pendarahan (30,3\%), hipertensi $(27,1 \%)$ dan infeksi $(7,3 \%)$ merupakan tiga faktor penyebab tertinggi kematian ibu. Adapun penyebab lain yaitu adanya kanker, ginjal, jantung, tuberkolosis dan penyakit lain yang diderita ibu (Kementerian Kesehatan Republik Indonesia, 2016).

AKI dan AKB di Daerah Istimewa Yogyakarta sering mengalami fluktuasi, di tahun 2017 AKI dan AKB masing-masing adalah 34 per 100.000 kelahiran hidup dan 313 per 1000 kelahiran hidup (Dinkes DIY, 2018). Kasus kematian paling banyak di Yogyakarta ada di daerah Kabupaten Gunung Kidul (12 kasus). Penyebab kematian tersebut adalah perdarahan dengan jumlah 1 kasus, jantung dengan jumlah 4 kasus, Pre Eklampsia Berat dan SLE dengan jumlah 1 kasus, eklampsia (1 kasus) , 2 kasus disebabkan oleh sepsis atau infeksi, 1 kasus disebabkan hipertiroid, emboli ketuban (jumlah kasus yaitu 1 kasus) dan pneumonia dengan jumlah 1 kasus (Dinas Kesehatan DIY, 2017).

Berdasarkan data di atas, kematian ibu akibat infeksi atau sepsis dapat terjadi terutama saat ibu berada dalam masa kehamilan hingga masa nifas. Sepsis pada masa nifas adalah penyebab kematian ibu paling penting yang terjadi secara langsung. Infeksi ini disebabkan oleh banyak hal. Beberapa penyebabnya antara lain kebersihan pada ruang bersalin, petugas yang menolong persalinan dan lainlain (Halder, Vijayselvi, and Jose 2015). Selain kebersihan ruang bersalin dan penolong persalinan, faktor penyebab infeksi lainnya adalah kemiskinan, jarak, kurang informasi, layanan yang tidak memadai dan praktik budaya (WHO 2018).

Banyak upaya untuk menurunan AKI. Upaya yang dilakukan antara lain dengan cara mengakses pelayanan kesehatan bagi ibu yang berkualitas, misalnya dengan pelayanan kesehatan selama hamil, pertolongan persalinan yang dilakukan tenaga kesehatan terlatih, perawatan pasca persalinan baik bagi ibu dan bayi dan lain sebagainya (Kementerian Kesehatan Republik Indonesia, 2016). Selain penurunan AKI, kematian ibu juga dapat dicegah dengan cara memberikan akses ke perawatan antenatal pada kehamilan, perawatan terampil selama persalinan, dan perawatan dan dukungan dalam beberapa minggu setelah melahirkan (WHO 2018).

Kondisi kesehatan seperti infeksi yang cukup banyak terjadi juga dapat dicegah dengan perilaku yang baik. Faktor-faktor yang mempengaruhi perilaku pencegahan infeksi antara lain: faktor kognitif atau (misalnya pengetahuan), sosial (hubungan sosial dengan lingkungan, kesadaran dari orang yang satu ke orang yang lain dan sebagainya) dan kondisi lain (informasi demografis seperti usia, pendidikan, status sosial dan ekonomi, status keluarga dan informasi dari luar) (Ali 2017; Weston, Hauck, and Amlôt 2018).

Pengetahuan berperan penting dalam pencegahan infeksi yang dialami. Semakin tinggi tingkat pendidikan yang dimiliki oleh seseorang maka akan mempengaruhi tingkat pengetahuan dalam melakukan suatu tindakan pencegahan infeksi (Sultana et al. 2018). Pendidikan untuk menambah pengetahuan sendiri dapat diperoleh secara formal maupun non formal seperti pemberian promosi atau pendidikan kesehatan (Azwar 2015). 


\section{METODE}

Penelitian ini merupakan penelitian kuantitatif. Metode yang digunakan adalah observasional analitik. Adapun rancangan penelitian yang digunakan dalam penelitian ini adalah survei cross sectional. Populasi dalam penelitian ini merupakan seluruh ibu nifas yang ada di RSUD Wonosari. Teknik pengambilan sampel yang digunakan adalah teknik Accidental Sampling. Adapun kriteria inklusi dalam penelitian ini adalah: (1) bersedia menjadi respoden; (2) ibu pasca bersalin normal yang rawat jalan maupun rawat inap; (3) mampu berbahasa Indonesia dengan cukup baik. Kriteria ekslusi dalam penelitian ini adalah ibu yang memiliki keterbatasan baik fisik maupun mental dan tidak bisa membaca. Sebanyak 67 responden diambil sebagai sampel. Lokasi atau tempat penelitian ini dilaksanakan yaitu di RSUD Wonosari yang berada di Kabupaten Gunungkidul. Pengumpulan data menggunakan kuesioner dengan analisa data bivariat menggunakan chi square. Kuesioner berisi 30 item pernyataan yang dimodifikasi dari beberapa penelitian sebelumnya dan telah di uji valid oleh para ahli (expert judgement). Sebanyak 20 item pernyataan tentang perilaku pencegahan infeksi dan 10 item pernyataan tentang pengetahuan. Sebanyak 20 item pernyataan ini terdiri dari 10 pernyataan bersifat positif dan 10 pernyataan bersifat negative. Sedangkan kuesioner pengetahuan berisi 10 pernyataan, dengan 4 pernyataan negatif dan 6 pernyataan positif.

\section{HASIL DAN PEMBAHASAN}

Berdasarkan hasil penelitian yang dilakukan, diperoleh data distribusi frekuensi karakteristik responden seperti yang tersedia dalam tabel 1 dibawah ini:

Tabel 1. Distribusi Frekuensi Karakteristik Responden

\begin{tabular}{lcc}
\hline \multicolumn{1}{c}{ Karakteristik } & $\begin{array}{c}\text { Frekuensi } \\
(\mathbf{n})\end{array}$ & $\begin{array}{c}\text { Persentase } \\
(\boldsymbol{\%})\end{array}$ \\
\hline Usia & 52 & 77,6 \\
Usia reproduktif sehat & 52 & 22,4 \\
Usia reproduktif tidak sehat & & \\
Pendidikan & 33 & 49,3 \\
Tinggi & 34 & 50,7 \\
Rendah & & 83,6 \\
Pengetahuan Ibu Nifas & 56 & 16,4 \\
Tinggi & 11 & 41,8 \\
Rendah & & 58,2 \\
Perilaku Pencegahan Infeksi & 28 & \\
Baik & 39 & \\
Kurang baik & &
\end{tabular}

Tabel distribusi frekuensi karakteristik responden dalam penelitian di RSUD Wonosari menunjukkan hasil yaitu sebanyak $52(77,6 \%)$ responden berada pada kategori usia reproduktif sehat, sedangkan sisanya termasuk kedalam kategori usia reproduktif tidak sehat. Sejumlah $34(50,7 \%)$ responden berada pada kategori pendidikan rendah, sedangkan sisanya memiliki kategori pendidikan tinggi. Lebih dari setengah responden memiliki pengetahuan dengan kategori tinggi yaitu sebanyak $56(83,6 \%)$, sedangkan $11(16,4)$ responden memiliki pengetahuan dengan kategori rendah. Sedangkan pada variabel perilaku, dapat disimpulkan 
bahwa sebanyak $39(58,2 \%)$ responden memiliki perilaku yang kurang baik, sedangkan sisanya memiliki perilaku dengan kategori baik.

Tabel 1. Tabel Hubungan Hubungan Pengetahuan Dengan Perilaku Pencegahan Infeksi Masa Nifas di RSUD Wonosari

\begin{tabular}{|c|c|c|c|c|c|c|c|c|}
\hline \multirow{3}{*}{ Variabel } & \multicolumn{4}{|c|}{$\begin{array}{c}\text { Perilaku Pencegahan } \\
\text { Infeksi }\end{array}$} & \multirow{3}{*}{$\begin{array}{c}p- \\
\text { value }\end{array}$} & \multirow{3}{*}{$\begin{array}{c}P R(95 \% \\
\text { CI })\end{array}$} & \multirow{3}{*}{$X^{2}$ hitung } & \multirow{3}{*}{$\mathbf{X}_{\text {tabel }}^{2}$} \\
\hline & \multicolumn{2}{|c|}{ Baik } & \multicolumn{2}{|c|}{$\begin{array}{c}\text { Kurang } \\
\text { Baik }\end{array}$} & & & & \\
\hline & $\mathbf{n}$ & $\%$ & $\mathrm{n}$ & $\%$ & & & & \\
\hline \multicolumn{9}{|l|}{ Pengetahuan } \\
\hline Tinggi & 25 & 44,6 & 31 & 55,4 & \multirow[b]{2}{*}{0,286} & 0,611 & \multirow[b]{2}{*}{1,140} & \multirow[b]{2}{*}{3,841} \\
\hline Rendah & 3 & 27,3 & 8 & 72,7 & & $\begin{array}{c}(0,223- \\
1,674)\end{array}$ & & \\
\hline
\end{tabular}

Hasil dari tabel analisis bivariat diketahui bahwa responden dengan kategori pengetahuan yang tinggi dan berperilaku kurang baik terhadap pencegahan infeksi ada sejumlah $31(55,4 \%)$ responden, sedangkan responden dengan kategori pendidikan rendah tetapi berperilaku baik yaitu sejumlah $25(44,6 \%)$ responden.

Uji statistik yang dilakukan memperoleh hasil $p$ value 0,286 . Hasil $\mathrm{X}^{2}$ hitung yang didapatkan memperlihatkan nilai yang lebih kecil dari $\mathrm{X}_{\text {tabel. Nilai yang }}^{2}$ diperoleh tersebut menunjukan bahwa pengetahuan dengan perilaku pencegahan infeksi secara statistik tidak memiliki hubungan. Apabila dilihat pada nilai PR yang dihasilkan dalam analisa ini disimpulkan bahwa pengetahuan tidak memiliki pengaruh atau sama saja atau bersifat protektif (PR 0,611; 95\% CI 0,223-1,674).

Perilaku dipengaruhi oleh tiga faktor yaitu faktor predisposisi, pemungkin dan penguat. Usia, pendidikan, paritas, pengetahuan dan budaya merupakan faktor predisposisi, sedangkan promosi kesehatan merupakan bagian dari faktor pemungkin yang mempengaruhi seseorang dalam berperilaku. Perilaku yang baik dapat diperoleh apabila responden mampu menyalin perilaku yang baru dimulai dengan adanya kesadaran dalam diri responden dan memiliki kertetarikan terhadap apa yang ada disekitarnya (Notoatmodjo 2014).

Penelitian yang dilakukan oleh Khaskheli, Baloch dan Sheeba menyebutkan bahwa kejadian sepsis sering menyerang wanita yang berada pada usia 31 tahun. Faktor lain yang dapat mempengaruhi adalah kebersihan, perawatan kebidanan, kemiskinan dan lain sebagainya (Khaskheli, Baloch, and Sheeba 2013). Usia sendiri berpengaruh dalam menentukan perilaku seseorang (Presty et al. 2020). Dalam penelitian Lamadah mengatakan bahwa wanita dalam rentang usia 20-40 tahun memiliki kecenderungan untuk menerapkan praktik yang baik dibandingkan usia $<30$ dan >dari 40 (Lamadah 2013).

Hasil dalam penelitian ini ditemukan bahwa lebih dari setengah responden berada dalam usia reproduksi yang sehat (usia 20-35 tahun). Kondisi ini menunjukkan bahwa responden yang diteliti di RSUD Wonosari sudah mengetahui bahwa kondisi yang aman untuk merencanakan kehamilan ataupun kelahiran adalah berada di usia yang baik untuk bereproduksi. Temuan ini sejalan dengan yang dijelaskan oleh Belliani, 2016 bahwa usia kehamilan remaja berisiko untuk remaja dan keturunan dari remaja itu sendiri, sementara pada usia yang lebih tua dapat menimbulkan banyak risiko kehamilan. Meskipun sebagian besar responden 
berada dalam usia reproduksi sehat, namun sebanyak $34(50,75)$ diketahui memiliki pendidikan yang rendah.

Tingkat Pendidikan yang tinggi akan mempermudah seseorang dalam menerima informasi, semakin banyak informasi yang diperoleh maka pengetahuan akan semakin baik (Keintjem \& Binambuni 2018). Faktor tersebut didukung oleh faktor lainnya seperti kurangnya pelayanan antenatal dan lain sebagainya (Bauserman et al. 2015). Namun pendidikan tidak langsung berpengaruh terhadap tingkat pengetahuan yang dimiliki oleh responden. Hal ini disebabkan oleh karena pengetahuan dapat diperoleh diluar dari pendidikan yang ditempuh oleh responden, misalnya pendidikan formal maupun non formal (Azwar 2015). Pendidikan non formal dapat diperoleh dari informasi yang diakses di media sosial, pengalaman pribadi ataupun pengalaman dari orang lain (Kartini et al. 2020).

Hasil analisa menunjukkan bahwa lebih dari setengah responden memiliki pengetahuan yang tinggi. Responden dapat memperoleh pengetahuan diluar pendidikan yang diperoleh, misalnya dengan mengikuti kelas ibu hamil selama kehamilan atau mendengarkan promosi kesehatan yang diperoleh selama perawatan yang diterima responden di RSUD Wonosari. Untuk mendukung pengetahuan seorang ibu, promosi kesehatan dapat membantu dalam peningkatan pengetahuan, sehingga dengan kesadaran penuh ibu dapat mengubah perilaku yang buruk menjadi lebih baik (Bao et al. 2010).

Women International Club Postpartum dalam modulnya menyampaikan bahwa ibu pasca melahirkan membutuhkan nutrisi yang memadai, diantaranya adalah asam folat, kalsium, besi, diet vegetarian (protein dan vitamin B12) dan cairan (WIC 2013). Pemenuhan nutrisi ini dapat membantu ibu dalam proses pemulihan pasca bersalin, terutama saat ibu memiliki luka pada jalan lahir. Protein berperan penting dalam proses penyembuhan luka (Mackay 2019).

Sebanyak 39 (58\%) responden memiliki perilaku yang kurang baik. Untuk meningkatkan kualitas kesehatan diperlukan Perilaku Hidup Bersih dan Sehat (PHBS) yang dapat diperoleh dari proses sadar pengetahuan dari individu dalam menjalani perilaku hidup yang menjaga kebersihan dan memenuhi standar kesehatan. PHBS dapat dilakukan baik di rumah tangga, sekolah, tempat umum, tempat kerja dan institusi kesehatan. Dalam penelitian ini PHBS dilakukan dalam tingkatan rumah tangga (Kemenkes RI 2011).

Berdasarkan analisis butir soal, diperoleh hasil bahwa lebih dari 35 responden hanya menggunakan air bersih saja saat mencuci tangan dan kurang banyak konsumsi buah dan sayur. Penggunaan air bersih dan konsumsi buah serta sayur merupakan dua indikator dalam perilaku hidup bersih dan sehat dalam tingkatan rumah tangga. Mencuci tangan menggunakan air bersih dan sabun merupakan langkah untuk mencegah penularan berbagai penyakit sedangkan konsumsi sayur dan buah dapat memenuhi kebutuhan vitamin dan mineral serta serat yang dibutuhkan tubuh (Kemenkes RI 2011).

Pengetahuan memegang peranan penting dalam berperilaku. Selain itu tingkat pengetahuan seseorang mampu membedakan proses pemulihan atau percepatan dari luka perineum (Rahayu 2017). Seseorang dengan pengetahuan yang rendah akan berisiko mengalami kejadian infeksi pada ibu nifas (Bao et al. 2010). Hal ini dapat terjadi karena ibu tidak tahu cara perawatan untuk mencegah infeksi maupun memperbaiki faktor predisposisi infeksi. 
Pengetahuan yang baik juga dapat mempercepat proses kesembuhan dari luka perineum pada ibu nifas. Pengetahuan yang kurang akan membawa ibu pada infeksi dan komplikasi postpartum (Mulia 2017). Penelitian yang dilakukan oleh Mole, Anggraeni dan Annas menghasilkan bahwa pengetahuan yang baik akan meningkatkan kesadaran dan sikap yang positif terhadap pengobatan luka perineum (Mole et al.2019).

Hasil penemuan menunjukkan bahwa responden dengan pengetahuan tinggi sebanyak $25(44,6 \%)$ responden memiliki perilaku pencegahan infeksi yang baik, sedangkan $31(55,4 \%)$ responden dengan kategori pengetahuan yang tinggi memiliki perilaku yang kurang baik. Adapun nilai $p$ value yang diperoleh yaitu 0,286. Nilai ini dapat diartikan bahwa pengetahuan tidak berhubungan dengan variable perilaku pencegahan infeksi yang terjadi pada ibu nifas.

Penelitian ini sejalan dengan yang disampaikan oleh Mathew, dimana hasil penelitiannya menyatakan bahwa tidak ada hubungan yang signifikan antara tingkat pengetahuan dari ibu primipara dengan sosio demografis antara lain usia, agama, tempat tinggal, status pekerjaan dan status pendidikan serta sumber informasi. Adapun nilai $p$ value pada masing-masing faktor sosio demografis adalah $>0,05$ (Mathew 2013).

Penelitian Safitri dkk juga menyebutkan bahwa pengetahuan dan sikap tidak berhubungan secara signifikan terhadap tradisi perawatan nifas dengan nilai $p$ value $>0,05$. Hal ini disebabkan meski ibu banyak mengetahui adanya tradisi, namun tidak semua ibu mau menjalankan atau mengikuti tradisi yang ada (Safitri et al. 2020).

Beberapa penelitian juga menyebutkan, selain variabel lama persalinan, ketersediaan makanan selama kehamilan, promosi kesehatan dan dukungan sosial, maka variabel lain seperti pendidikan, pendapatan, status pernikahan, jenis persalinan, pengetahuan tentang sepsis perineum, usia, pendidikan, agama dan variabel lainnya ditemukan hasil tidak ada hubungan yang signifikan (Chepchirchir et al. 2017; Choi \& Jung 2017).

Hasil penelitian ini tidak sejalan dengan penelitian yang dilakukan oleh Sultana, dimana hasilnya menyebutkan bahwa pengetahuan yang dimiliki oleh ibu postpartum berpengaruh terhadap praktik pencegahan infeksi (Sultana et al. 2018). Hasil penelitian yang dilakukan oleh Mirzaee menyebutkan bahwa hasil yang diperoleh tidak sejalan. Dimana hasil penelitian tersebut menunjukkan hasil terdapat hubungan yang signifikan antara variabel pengetahuan dan karakteristik demografis dengan nilai $p$ value yang diperoleh <0,05 (Mirzaee et al. 2015).

Beberapa penelitian lain juga tidak sependapat dengan temuan ini. Penelitian yang dilakukan oleh Eldawati menyebutkan bahwa pengetahuan berkaitan dengan praktik perawatan masa nifas. Eldawati menyebutkan bahwa pengetahuan yang dimiliki oleh seseorang akan berdampak dengan perilaku yang ditimbulkan. Begitu juga dengan penelitian yang dilakukan oleh Nurrahmaton dan Dewi dengan hasil yaitu pengetahuan berhubungan secara signifikan dengan proses penyembuhan luka ibu nifas (Eldawati 2015; Nurrahmaton \& Sartika 2018).

Temuan lain juga menyebutkan bahwa pengetahuan memiliki hubungan yang signifikan terhadap variabel demografis. Pengetahuan ibu tentang perawatan pascakelahiran berada pada tingkat sedang sedang. Pengetahuan berada dalam kategori tinggi dalam tanda bahaya dan pengetahuan dengan kategori rendah adalah 
keluarga berencana. Program penyadaran diperlukan untuk meningkatkan pengetahuan ibu tentang perawatan pasca persalinan (Sandhya and Rojana 2015).

Analisis butir soal pada kuesioner yang diberikan, menunjukkan hasil bahwa sebanyak $46(68,65 \%)$ responden memiliki pengetahuan yang rendah terhadap pemahaman mengenai penyebab peradangan atau infeksi dan sebanyak 60 $(89,55 \%)$ responden memiliki pengetahuan yang rendah terhadap pemahaman risiko peningkatan infeksi. Pengetahuan yang rendah dapat menjadi faktor risiko dalam kejadian infeksi (Bao et al. 2010). Untuk itu diperlukan promosi kesehatan guna menambah pengetahuan dari responden.

Selain hal diatas, juga ditemukan ibu postpartum memegang kebudayaan yang cukup kuat. Salah satunya pantang makanan berbau amis seperti ikan. Praktik budaya yang bersifat negatif ini dapat menyebabkan seseorang rentan terhadap kejadian infeksi. Hal ini disebabkan oleh karena kurangnya nutrisi yang diperoleh ibu dapat menyebabkan ibu mengalami ketidakmampuan atau keterlambatan dalam kesembuhan luka yang diperoleh ibu selama proses kelahiran, tidak hanya menjadi risiko bagi ibu, bayi dapat menerima efek negatif apabila ibu masih melakukan praktik kebudayaan yang bersifat negatif (Lamxay et al. 2011; Molnar et al. 2014).

Kelemahan yang ditemukan dalam penelitian ini adalah karakteristik responden yang diekplorasi tidak banyak, sehingga mengurangi data yang seharusnya dapat dibahas. Selain itu uji bivariat yang dilakukan hanya pada variabel pengetahuan dengan perilaku pencegahan infeksi sedangkan variabel usia dan pendidikan tidak dilakukan. Untuk itu perlu dilakukan penelitian lebih lanjut tentang karakteristik responden yang lain mengingat banyak faktor dapat mempengaruhi perilaku seseorang. Beberapa karakteristik yang dapat diuji lebih lanjut antara lain usia, pendidikan, kebudayaan, promosi kesehatan, paritas dan karakteristik lainnya.

\section{SIMPULAN}

Berdasarkan hasil yang diperoleh, diketahui bahwa pengetahuan tidak memiliki hubungan yang signifikan terhadap perilaku pencegahan infeksi. Hasil ini terlihat pada nilai $p$ value yang diperoleh lebih dari 0,05 dan hasil $\mathrm{X}^{2}{ }_{\text {hitung }}$ yang diperoleh menunjukkan nilai yang lebih kecil dari $\mathrm{X}^{2}$ tabel. Meskipun tidak menunjukkan hasil yang signifikan, namun perlu dilakukan penelitian lebih lanjut, mengingat bahwa faktor yang mempengaruhi perilaku tidak terdiri satu faktor saja namun lebih. Beberapa karakteristik yang dapat diuji lebih lanjut antara lain usia, pendidikan, kebudayaan, promosi kesehatan, paritas dan karakteristik lainnya.

\section{DAFTAR PUSTAKA}

Ali, Rizky Nikmathul Husna. 2017. "Hubungan Tingkat Pengetahuan Dan Sikap Ibu Dengan Penggunaan Pengobatan Alternatif Dan Komplementer Selama Kehamilan Di RSIA Sakina Idaman Sleman." 'Aisyiyah.

Azwar. 2015. Sikap Manusia: Teori Dan Pengukurannya. Yogyakarta: Pustaka Belajar.

Bao, Wei, Aiguo Ma, Limei Mao, Jianqiang Lai, Mei Xiao, Guoqiang Sun, 
Yingying Ouyang, Shuang Wu, Wei Yang, Nanping Wang, Yanting Zhao, Juan Fu, and Liegang Liu. 2010. "Diet and Lifestyle Interventions in Postpartum Women in China: Study Design and Rationale of a Multicenter Randomized Controlled Trial." BMC Public Health 10. doi: 10.1186/14712458-10-103.

Bauserman, Melissa, Adrien Lokangaka, Vanessa Thorsten, Antoinette Tshefu, Shivaprasad S. Goudar, Fabian Esamai, Ana Garces, Sarah Saleem, Omrana Pasha, Archana Patel, Albert Manasyan, Mabel Berrueta, Bhala Kodkany, Elwyn Chomba, Edward A. Liechty, K. Michael Hambidge, Nancy F. Krebs, Richard J. Derman, Patricia L. Hibberd, Fernando Althabe, Waldemar A. Carlo, Marion Koso-Thomas, Robert L. Goldenberg, Dennis D. Wallace, Elizabeth M. McClure, and Carl L. Bose. 2015. "Risk Factors for Maternal Death and Trends in Maternal Mortality in Low- and Middle-Income Countries: A Prospective Longitudinal Cohort Analysis." Reproductive Health 12(2):S5. doi: 10.1186/1742-4755-12-S2-S5.

Chepchirchir, Maritim Violet, Jackim Nyamari, and Margaret Keraka. 2017. "Associated Factors with Puerperal Sepsis among Reproductive Age Women in Nandi County, Kenya." 5(4):1032-40. doi: 10.22038/jmrh.2017.9348.

Choi, Hyekyung, and Namok Jung. 2017. "Factors Influencing Health Promoting Behavior in Postpartum Women at Sanhujoriwon." Korean Journal of Women Health Nursing 23(2):135. doi: 10.4069/kjwhn.2017.23.2.135.

Dinkes DIY. 2017. "Profil Kesehatan Provinsi Daerah Istimewa Yogyakarta Tahun 2017." Dinas Kesehatan DIY 1-224.

Eldawati, Sagita. 2015. "Hubungan Pengetahuan dan Sikap Ibu Nifas dengan Praktik Perawatan Masa Nifas di Kecamatan Gunungpati Kota Semarang bulan Januari-Maret 2015." 3(April):228-37.

Halder, Ajay, Reeta Vijayselvi, and Ruby Jose. 2015. "Changing Perspectives of Infectious Causes of Maternal Mortality." Journal of the Turkish German Gynecology Association 16(4):208-13. doi: 10.5152/jtgga.2015.0134.

Kartini, Farida, Ova Emilia, Djaswadi Dasuki, Yayi Suryo Prabandari, and Sri Handayani. 2020. "Gambaran Tingkat Pengetahuan Ibu Hamil Trimester III Mengenai Persalinan." Jurnal Kebidanan Dan Keperawatan Aisyiyah 15(2):202-11. doi: 10.31101/jkk.1164.

Kemenkes RI. 2011. "Promosi Kesehatan Di Daerah Bermasalah Kesehatan." Jakarta: Kementrian Kesehatan RI Pusat Promosi Kesehatan.

Kementerian Kesehatan Republik Indonesia. 2016. Profil Kesehatan Indonesia 2016.

Khaskheli, Meharun Nissa, Shahla Baloch, and Aneela Sheeba. 2013. "Risk Factors and Complications of Puerperal Sepsis at a Tertiary Healthcare Centre." Pakistan Journal of Medical Sciences 29(4):972-77. doi: 10.12669/pjms.294.3389. 
Lamxay, Vichith, Hugo J. de Boer, and Lars Björk. 2011. "Traditions and Plant Use during Pregnancy, Childbirth and Postpartum Recovery by the Kry Ethnic Group in Lao PDR." Journal of Ethnobiology and Ethnomedicine 7(1):14. doi: 10.1186/1746-4269-7-14.

Losu, Freidrika Nancy, Femmy Keintjem, and Sridayanti Binambuni. 2018. "Hubungan Pengetahuan Dengan Sikap Ibu Nifas Tentang Perawatan Luka Perineum Di RSU GMIM Pancaran Kasih Manado." 5:68-76.

Mackay, Ellen. 2019. "The Power of Protein in Wound Healing." Wound Care Canada 17(1):34-37.

Mansour Lamadah, Sahar. 2013. "Postpartum Traditional Beliefs and Practices among Women in Makkah Al Mukkaramah, KSA." Life Science Journal 10(2):838-47.

Mathew, Rinku. 2013. "A Study to Assess the Effectiveness of Structured Teaching Programme on Prevention of Puerperal Infections among Primi Postnatal Mothers in Selected Hospitals at Mangalore." Rajiv Gandhi University of Health Sciences,.

Mirzaee, Khadijeh, Somayyeh Oladi Ghadikolaee, Mohamad Taghi Shakeri, Mojtaba Mousavi Bazzaz, and Assistant Professor. 2015. "Maternal Knowledge on Postpartum Care in Healthcare Centers of Mashhad, Iran in 2013." Journal of Midwifery and Reproductive Health 3(4):456-64.

Mole, Marselina, Mekar DwiAnggraeni, and Annas Sumeru. 2019. "The Relationship between Level of Knowledge about Vulva Hygiene and the Restrictions during Childbirth with the Perineal Wound Healing among Postpartum Mothers Page." Annals of Tropical Medicine and Public Health 22(11). doi: 10.36295/ASRO.2019.221146.

Molnar, Joseph Andrew, Mary Jane Underdown, and William Andrew Clark. 2014. "Nutrition and Chronic Wounds." Advances in Wound Care 3(11):663-81. doi: 10.1089/wound.2014.0530.

Mulia, Sari. 2017. “Analysis Of Knowledge And Attitudes On Perineal Wound Healing In Postpartum Mother In The Area Of Pekauman Public Health Center In South Banjarmasin.” 6(Smichs):586-94.

Notoatmodjo, Soekidjo. 2014. Promosi Kesehatan Dan Perilaku Kesehatan. Revisi. Jakarta: Rineka Cipta.

Nurrahmaton, Nurrahmaton, and Dewi Sartika. 2018. "Hubungan Pengetahuan Ibu Post Partum Tentang Perawatan Luka Perineum Dengan Proses Penyembuhan Luka Di Klinik Bersalin Hj. Nirmala Sapni, Amkeb Medan.” Jurnal Bidan Komunitas 1(1):20. doi: 10.33085/jbk.v1i1.3911.

Presty, Marsela Renasari;, Djaswadi; Dasuki, Yuli; Isnaeni, and Ni Nyoman Yeyen Abriani. 2020. "Penelitian Ini Menggunakan Teknik Digunakan Sampling . Pengambilan Adalah Sampel Sampel Yang Penelitian Kuantitatif Dengan Metode Observasional Analitik Dan Rancangan Penelitian Survei Cross 
Sectional . Populasi Dalam Penelitian Ini Adalah Seluruh Ibu Nif.” 10:52531.

Rahayu, Yayuk Puji et al. 2017. "Advances in Health Science Research, Volume 6 2nd Sari Mulia International Conference on Health and Sciences (SMICHS 2017)." 6(Smichs):1-11.

Safitri, Faradilla, Nuzulul Rahmi, and Karisma Melati. 2020. "Perilaku Ibu Terhadap Tradisi Perawatan Masa Nifas Di Wilayah Kerja Puskesmas Jeulingke Kota Banda Aceh Mother Behavior Towards Tradition of Postnatal Care in Jeulingke Community Health Centre of Banda Aceh District.” 6(1).

Sandhya, Timilsina, and Dhakal Rojana. 2015. "Knowledge on Postnatal Care Among Postnatal Mothers." Saudi Journal of Medical and Pharmaceutical Sciences 1(4):87-92.

Sultana, Shirin, Fatema Zohora Methe, Faisal Muhammad, and ABM Alauddin Chowdhury. 2018. "Knowledge and Practice Regarding Prevention of Puerperal Sepsis among Postpartum Women Attending a Private Hospital in Bangladesh." International Journal of Research in Medical Sciences 6(10):3264. doi: 10.18203/2320-6012.ijrms20184029.

Weston, Dale, Katharina Hauck, and Richard Amlôt. 2018. "Infection Prevention Behaviour and Infectious Disease Modelling: A Review of the Literature and Recommendations for the Future." BMC Public Health 18(1):1-16. doi: 10.1186/s12889-018-5223-1.

WHO. 2018. "Maternal Mortality." Retrieved September 10, 2020 (https://www.who.int/news-room/fact-sheets/detail/maternal-mortality).

WIC. 2013. "WIC Postpartum Nutrition.” 2012:1-14. 